\title{
Analysis of microbial fuel cell operation in acidic conditions using the flocculating agent ferric chloride
}

\author{
Jonathan Winfield, John Greenman, Julian Dennis and Ioannis Ieropoulos
}

\begin{abstract}
BACKGROUND: Ferric chloride $\left(\mathrm{FeCl}_{3}\right)$ is widely used as a flocculating agent during wastewater treatment but can detrimentally lower $\mathrm{pH}$ and increase iron concentration. Microbial fuel cells (MFCs) are a promising technology for treating waste while concomitantly producing electricity and so were tested under the extreme conditions imposed by the addition of $\mathrm{FeCl}_{3}$. MFCs were fed eight concentrations of $\mathrm{FeCl}_{3}$ over two 8-week periods and the effects on power, $\mathrm{pH}$, conductivity, metal content and COD were examined. RESULTS: MFCs generated highest power $\left(3.58 \mathrm{Wm}^{-3}\right)$ at $1.6 \mathrm{mmol} \mathrm{L}^{-1} \mathrm{FeCl}_{3}(\mathrm{pH} 3.46)$, however cells reversed when fed $2 \mathrm{mmol} \mathrm{L}^{-1}$ (pH 3.29). During the second run, power almost doubled and MFCs were more resilient at higher loadings up to $2.8 \mathrm{mmol} \mathrm{L}^{-1}$ (pH 3.02). Conductivity and $\mathrm{pH}$ increased following treatment while soluble phosphorus, sulphur and iron levels decreased significantly in all feedstock up to $1.6 \mathrm{mmol} \mathrm{L}^{-1} \mathrm{FeCl}_{3}$. COD reduction was observed but efficiency may have been affected by the presence of alternative electron donors such as hydrogen sulphide.

CONCLUSION: These findings demonstrate the robustness and versatility of MFCs in hostile conditions. They also confirm that MFCs can complement current wastewater treatment processes, even downstream from $\mathrm{FeCl}_{3}$ dosing where conditions might be deemed unsuitable for operation.
\end{abstract}

Keywords: Microbial fuel cell; ferric chloride; wastewater; flocculation; coagulation; acidic

\section{INTRODUCTION}

Microbial fuel cells (MFCs) offer an intriguing solution for wastewater treatment because they utilise the organic pollutants in a waste stream as fuel for the generation of electricity. ${ }^{1}$ Anaerobic microorganisms are responsible for oxidising organic matter and adopting an electrode (anode) as a terminal electron acceptor. The electrons flow around an external circuit from the anode to an open-to-air cathode, which causes an electric current flow. Where MFCs might fit in to existing wastewater systems is yet to be established and it is unlikely that treatment companies will rush to completely replace existing technologies that 
have long been tried and tested. Therefore, a likely route to implementing MFCs for wastewater treatment is to integrate them into existing processes thus enhancing treatment efficiency while providing additional power production. With this in mind, MFCs should be tested in adverse conditions that might be encountered in a real wastewater environment. During conventional wastewater treatment, influent is often dosed with ferric salts either as iron sulphate $\left(\mathrm{Fe}_{2}(\mathrm{SO} 4)_{3}\right)$ or iron chloride $\left(\mathrm{FeCl}_{3}\right)$ to achieve phosphorus precipitation and flocculation/coagulation of organic matter. Naturally occurring electrostatic interactions lead to repulsions between colloids ${ }^{2}$ and through the addition of chemicals, the charge is neutralised. Once neutralised the colloids are attracted to each other and collide and form clumps of material or 'flocs'. Ferric salts are also used to control hydrogen sulphide $\left(\mathrm{H}_{2} \mathrm{~S}\right)$ build up in concrete sewage systems, a problem that if not dealt with can cause corrosion, obnoxious odours and toxic gases. ${ }^{3}$ In addition to the cost of materials and maintenance, the use of ferric salts can introduce complications such as increased levels of iron and acidification; the latter is often dealt with by adding other chemicals (e.g. lime) resulting in further financial cost. In other areas of research, microbial biofilms have been demonstrated to neutralise acidity and reduce the high metal content of effluents ${ }^{4}$ and so an interesting angle would be the use of MFCs, with constituent biofilm electrodes, in an environment similar to that found during flocculation. The addition of ferric salts can take place at various stages of wastewater treatment and so MFCs incorporated into existing infrastructure would very likely be exposed to these hostile conditions. This environment with low $\mathrm{pH}$ and high iron content might be deemed unfavourable, particularly considering that MFCs have been reported to demonstrate improved performance under alkaline conditions. ${ }^{5}$ For example, a higher $\mathrm{pH}$ has been demonstrated to enhance the electrochemical activity of riboflavin which is a metabolite responsible for extracellular electron transfer in some species. ${ }^{6}$ However, previous research has shown the capacity for electro-active microbes in MFCs to operate in extreme conditions. Examples include thermophilic, ${ }^{7}$ haloalkaliphilic, ${ }^{8}$ psychrophilic, ${ }^{9}$ and conditions rich in toxic metal ions, e.g. landfill leachate. ${ }^{10}$ Ferric iron has previously been used in MFCs as part of the cathode half-cell reaction. For example, the ferric/ferrous iron couple was demonstrated to be an efficient mediator of oxygen reduction at the cathode. ${ }^{11}$ Another study used high concentrations of iron chloride to produce synthetic acid mine drainage with high iron content and low $\mathrm{pH}$ that was successfully utilised as catholyte. ${ }^{12}$ In terms of the anode half-cell reaction, Wu et al. ${ }^{13}$ used ferric citrate to improve start-up time and performance using Shewanella oneidensis, however, the $\mathrm{pH}$ was maintained at 7. MFCs have successfully been operated under acidic anode conditions; Barole et al. ${ }^{14}$ 
operated MFCs at pH levels less than 4.0 and Malki et al. ${ }^{15}$ produced high current densities using acidophiles under poised electrode potential conditions. The current study takes the next novel step by subjecting MFCs to various concentrations of ferric chloride without adjusting the $\mathrm{pH}$. For wastewater treatment companies, a technology that is able to increase $\mathrm{pH}$, decrease COD and remove problematic metals would be ideal. Therefore these specific traits were investigated.

\section{EXPERIMENTAL}

\subsection{MFC design and construction}

Miniature tubular MFCs were built as previously described. ${ }^{16} \mathrm{~A} 0.5 \times 0.5 \mathrm{~cm}^{2} \mathrm{CEM}$ (VWR, Leicestershire, UK) window was incorporated into a $1 \mathrm{~mL}$ pipette tip, which acted as the anode chamber. The anode was constructed using untreated carbon veil (total surface area: 10 $\mathrm{cm}^{2}$ ) that was folded in half and rolled to create a porous cylindrical 3D structure (projected surface area: $1.96 \mathrm{~cm}^{2}$ ). Nickel-chrome wire made the connection point with the electrode. Silicon tubing enclosed the pipette tip to make a water-tight seal and a window was cut to expose the CEM. The cathode $\left(4 \times 10 \mathrm{~cm}^{2}\right.$ piece of untreated carbon veil) was wrapped around the CEM window and nickel chrome wire used as the current collector. Two pieces of parafilm were wrapped around to hold the cathode firmly against the window and keep the wire secured. The upper end of the tubing was used as the anolyte entry point and the bottom as the exit point. To enable fluid flow over the cathodes, the MFC was sealed inside a larger piece of silicon tubing (130mm in length with a $16 \mathrm{~mm}$ internal diameter), which provided a covered flow-through environment for the cathode. Holes were cut for the current collecting wires (which were wrapped in parafilm to ensure electrical insulation) and the anolyte inlet and outlet tubes. These were sealed with an aquarium sealant (Wet Water Sticky Stuff, Barry Read Supplies, Ivybridge, UK). The MFC was now concealed within the external tube, enabling anodic flow through the inner tube, and cathodic flow through the larger outer tube.

\subsection{Abiotic reactors}

For the abiotic control experiment two reactors (as described in previous section) were operated without any inoculation, i.e. with no microbes present. The anodes were fed at $1.5 \mathrm{~mL} \mathrm{~h}^{-1}$ TYE (0.1\% tryptone, $0.05 \%$ yeast extract) either containing $\mathrm{FeCl}_{3}\left(0.375 \mathrm{~g} \mathrm{~L}^{-1}\right)$ or without any ferric chloride in order to examine whether there was any chemical contribution to power generation. The cathodes were hydrated with tap water at a flow rate of $90 \mathrm{~mL} \mathrm{~h}^{-1}$. 


\subsection{MFC inoculation and operation}

MFCs were inoculated using primary wastewater effluent enriched with TYE (1\% tryptone and $0.5 \%$ yeast extract $)$ and $\mathrm{FeCl}_{3}\left(0.375 \mathrm{~g} \mathrm{~L}^{-1}\right)$. This $\mathrm{FeCl}_{3}$ concentration $\left(1.2 \mathrm{mmol} \mathrm{L}^{-1}\right)$ was selected because it has been reported to be the optimum quantity for use in membrane bioreactors. ${ }^{17}$ For the maturing stage, this was fed at $1.5 \mathrm{~mL} \mathrm{~h}^{-1}$ in a cyclic fashion and the cathode was hydrated with tap water at the same flow-rate. After 3 days running under open circuit conditions, an $8.2 \mathrm{k} \Omega$ resistor was applied to each MFC. A fresh inoculum was fed after approximately 2 weeks. This relatively high $\mathrm{R}_{\mathrm{EXT}}$ was found to be the optimal load following preliminary experiments using the same small-scale MFCs. At the end of the fourth week, polarisation sweeps were performed where 'healthy'(overshoot-free) power curves verified stable performance. ${ }^{18}$ The subject biotic MFCs were then fed with a feedstock made up using a lower concentration of TYE (0.1\% tryptone and $0.05 \%$ yeast extract) with added $\mathrm{FeCl}_{3}$ which was fed at a flow rate of $1.5 \mathrm{mLh}^{-1}$. Tap water was used as the catholyte and was supplied at a flow rate of $90 \mathrm{~mL} \mathrm{~h}^{-1}$. Each $\mathrm{FeCl}_{3}$ concentration was fed to the MFCs for seven days before the next concentration was tested. A total of eight concentrations were investigated starting at 0 and going up to $2.8 \mathrm{mmol} \mathrm{L}^{-1}$. At the end of each week, polarisation experiments were performed. Following the first set of experiments, the MFCs were fed continuously for 5 weeks using the mid-range $\mathrm{FeCl}_{3}$ concentration $\left(1.2 \mathrm{mmol} \mathrm{L}^{-1}\right)$. After the 5-week stabilisation period a second run of experiments was performed where each of the concentrations was fed again for seven day periods starting at 0 and working up to $2.8 \mathrm{mmol}$ $\mathrm{L}^{-1}$. Duplicate MFCs were employed and all experiments were operated under identical conditions at ambient temperature conditions (22 $\pm 2 \circ \mathrm{C})$.

\subsection{Analysis}

Polarisation and power experiments were carried out using a variable resistor (Centrad Boite A Decades De Resistances DR07). Data were produced by sweeping 69 resistor values starting at $5 \mathrm{M} \Omega$ and gradually decreasing to $50 \Omega$. The time interval between resistance changes was 1 min. Recorded data were processed and analysed using the GraphPad Prism version 6 software package (GraphPad, San Diego, California, USA). Current (I) in amperes (A) was calculated using Ohm's law, I = V/R, where V is the measured voltage in volts (V) and $\mathrm{R}$ is the known value of the external load resistor in ohms $(\Omega)$. Power $(\mathrm{P})$ in watts $(\mathrm{W})$ was calculated by multiplying voltage with current: $\mathrm{P}=\mathrm{I} \times \mathrm{V}$. To calculate power and current densities the data were normalised to the anode chamber volume ( $1 \mathrm{~mL}$ total). The $\mathrm{pH}$ was 
measured using a pH meter (HANNA pH 209) and conductivity using a multi-range conductivity meter (HANNA Instruments HI 9033).

\subsection{COD, EDX and ICP-OES}

Samples of feedstock before treatment and after treatment were filter-sterilised. The liquid samples were analysed using inductively coupled plasma - optical emission spectrometry (ICP-OES, Varian Inc. Vista-Pro) to determine the soluble elements present. For COD, $2 \mathrm{~mL}$ samples were taken before and after MFC treatment and filter-sterilised prior to analysis. COD was determined using the potassium dichromate oxidation method (COD MR test vials, VWR, Lutterworth, England) and analysed with an Aquagem photometer (Jenway, Chelmsford, England) using a COD interference filter module (Jenway, Chelmsford, England). For precipitated mass, energy-dispersive X-ray (EDX) spectroscopy was performed using Philips XL30 SEM to determine the elements present in the solid samples.

\section{RESULTS AND DISCUSSION}

\subsection{Power generation at varying $\mathrm{FeCl}_{3}$ concentration}

The concentration of ferric salt used by wastewater treatment companies varies from plant to plant depending on flow-rate and phosphate levels. Those used in the current study were selected based on a theoretical optimum of $1.2 \mathrm{mmol} \mathrm{L}^{-1}$ as previously reported by Zhang et $a l .{ }^{17}$ for membrane bioreactors. At the end of each week at each concentration, polarisation sweeps were performed and the point of maximum power was obtained from the data. Over the first set of experiments there was an initial decline in performance from $0 \mathrm{mmol} \mathrm{L}^{-1}$ to 0.4 mmol L-1 $\mathrm{FeCl}_{3}$ (Fig. 1). This was followed by a gradual increase in power, reaching a maximum at $1.6 \mathrm{mmol} \mathrm{L}^{-1}$, before a sharp decline was observed when the $2 \mathrm{mmol} \mathrm{L}^{-1} \mathrm{FeCl}_{3}$ feedstock was used. MFCs underwent cell reversal following the polarisation sweep when fed $2 \mathrm{mmol} \mathrm{L}^{-1}$ and only recovered after several days of feeding with feedstock containing a lower concentration of $\mathrm{FeCl}_{3}\left(1.2 \mathrm{mmol} \mathrm{L}^{-1}\right)$. The MFCs were left to run on this feedstock for a further 5 weeks before the same set of experiments was performed again. Compared with the earlier run, power output improved almost two-fold at each concentration as illustrated in Fig. 1. Furthermore, the MFCs' tolerance increased where, despite the drop at $2 \mathrm{mmol} \mathrm{L}^{-1}$, there was no longer any cell reversal, and this was true even for the $2.4 \mathrm{mmol} \mathrm{L}^{-1}$ concentration, at which the MFC behaviour remained relatively stable. When the feedstock containing $2.8 \mathrm{mmol} \mathrm{L}^{-1} \mathrm{FeCl}_{3}$ was introduced, all MFCs showed a sharp decline and following polarisation, they underwent cell reversal. The MFCs did recover after several days 
of feeding with the feedstock containing $1.2 \mathrm{mmol} \mathrm{L}^{-1} \mathrm{FeCl}_{3}$. The production of power is indivisibly linked to the microbes' metabolism and so reflects the health of the biofilm at each concentration. Furthermore, the biological and therefore dynamic nature of MFCs will be critical for operation in a heterogeneous environment and as these results suggest, the MFCs are capable of adaptation to an inhospitable environment.

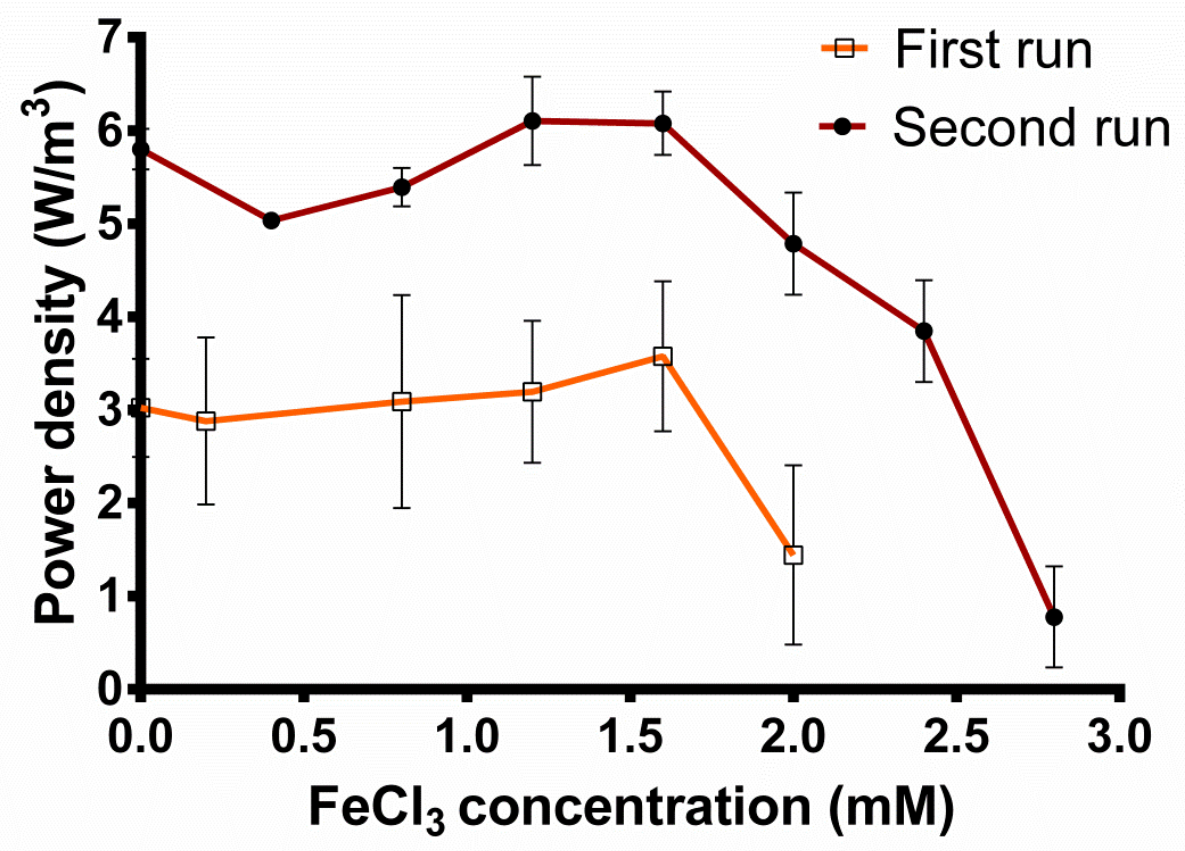

Figure 1. Maximum power densities obtained at different $\mathrm{FeCl}_{3}$ concentrations. Each concentration was fed to MFCs for a 7-day period with a polarisation sweep performed on the seventh day. First run of experiments was performed 5 weeks prior to the second run. Data presented are based on the mean of two units $(n=2)$.

\subsection{Assessing natural chemical redox balance}

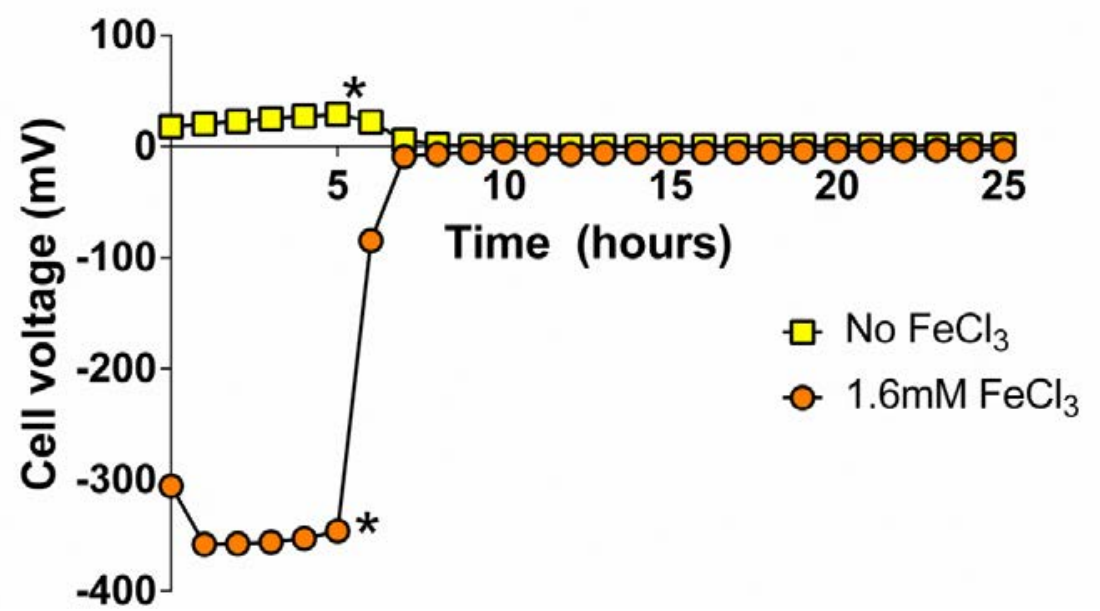

Figure 2. Behaviour of abiotic MFCs in open circuit and under-load conditions, when fed synthetic wastewater (TYE) either containing $\mathrm{FeCl}_{3}\left(1.6 \mathrm{mmol} \mathrm{L}^{-1}\right)$ or without. Asterisk indicates point when $8.2 \mathrm{k} \Omega$ resistors applied. 
Under the right conditions, i.e. $\mathrm{pH}$, materials, and temperature, power can be produced chemically from iron-rich anolytes (synthetic acid mine drainage) using abiotic cells. ${ }^{19}$ In order to examine the importance of microbes in the current study and to test that power output was not solely the result of chemical reactions or steep $\mathrm{pH}$ gradients, two control abiotic reactors were fed feedstock (TYE) either with or without $\mathrm{FeCl}_{3}\left(1.6 \mathrm{mmol} \mathrm{L}^{-1}\right)$. Figure 2 shows that a negative voltage was produced from the feedstock containing $\mathrm{FeCl}_{3}$, where the open circuit voltage (OCV) was $-346 \mathrm{mV}$ (average over $5 \mathrm{~h}$ ) and when a load was applied, a steady voltage with an average of $-4.9 \mathrm{mV}$ over $21 \mathrm{~h}$ was observed. The negative albeit low current suggests that some electrons were being donated at the cathode perhaps via a constituent of the catholyte (tap water). The fuel cells fed with TYE without $\mathrm{FeCl}_{3}$ generated an OCV of $23.6 \mathrm{mV}$ (average over $5 \mathrm{~h}$ ) and under load they produced a steady positive voltage of $1.56 \mathrm{mV}$ (average over $21 \mathrm{~h}$ ). These data confirm that, in the absence of microbes, neither $\mathrm{pH}$ gradient nor chemicals were contributing to power generation with the ferric chloride containing feedstock. This also shows the importance of the anodic biofilm, able to alter the natural redox conditions in order to produce a favourable environment suitable for microbial survival and the production of power. As discussed previously, when the concentration of ferric chloride became excessively high and the $\mathrm{pH}$ intolerably low (2 mmol $\mathrm{L}^{-1}$ in first run and $2.8 \mathrm{mmol} \mathrm{L}^{-1}$ during second run) the microbial contingent could no longer metabolise and power output declined. As a result of this microbial inhibition, the redox conditions reverted to their natural chemical state as reflected by cell reversal.

\section{$3.3 \mathrm{pH}$ and conductivity}

Following treatment, the feedstock containing concentrations of $\mathrm{FeCl}_{3}$ in the range of 0.4 to $1.6 \mathrm{mmol} \mathrm{L}^{-1}$, became darker in colour. At these concentrations, the $\mathrm{pH}$ (Fig. 3a) and the conductivity (Fig. 3b) increased considerably after passing through the MFCs. In contrast, the feedstock containing the higher concentrations of $\mathrm{FeCl}_{3}\left(2-2.8 \mathrm{mmol} \mathrm{L}^{-1}\right)$, remained visibly unchanged and although there was a small increase in $\mathrm{pH}$ at $2 \mathrm{mmol} \mathrm{L}^{-1}$, the $\mathrm{pH}$ and conductivity remained the same following treatment. There are a number of microbial processes that can result in increased $\mathrm{pH}$ and these include; denitrification, methanogenesis,

sulphate reduction and iron reduction. ${ }^{20}$ Following treatment the formation of black precipitates were detected and the familiar smell of hydrogen sulphide was apparent. ${ }^{21}$ Within the anode chamber it is posited that synergistic microbial processes were responsible for the increase in $\mathrm{pH}$ where fermentation products such as short chain fatty acids were supporting the growth of sulphate reducing bacteria (SRB). 

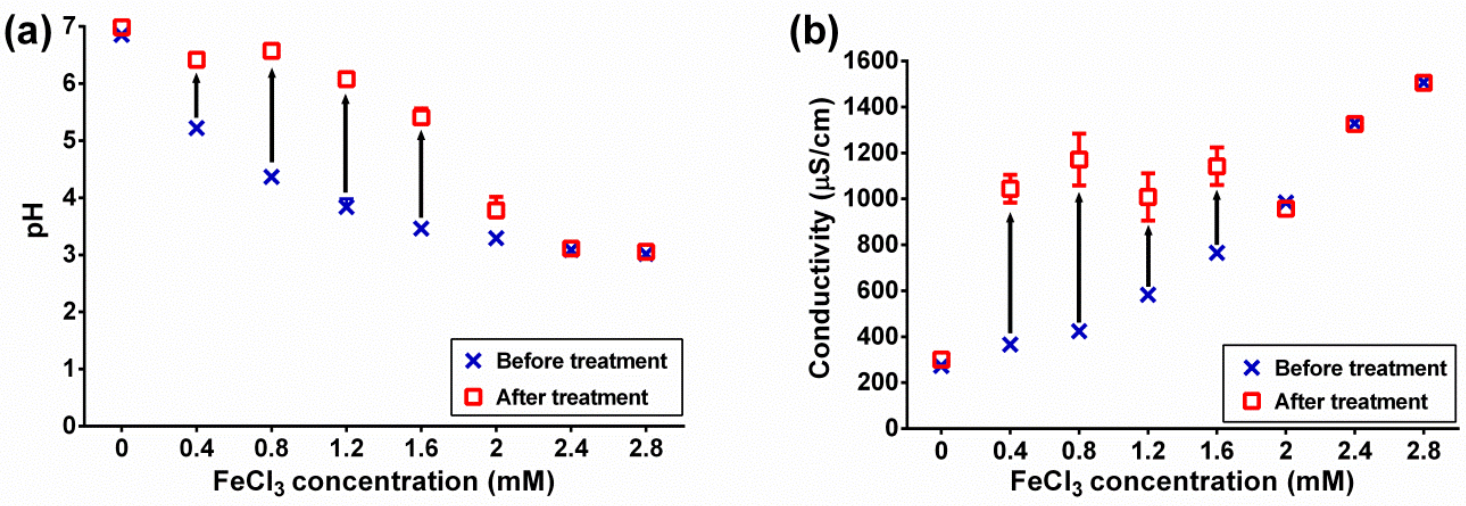

Figure 3. Change in (a) $\mathrm{pH}$ and (b) conductivity following MFC treatment at various $\mathrm{FeCl}_{3}$ concentrations. Error bars show the mean and SEM $(n=3)$.

The SRB reduce sulphate to hydrogen sulphide and so strong acid is transformed into weak acid via the consumption of hydrogen ions and the production of bicarbonate. ${ }^{20}$ It can safely be assumed that the increase in $\mathrm{pH}$ has assisted the microbial metabolism, which would have inevitably contributed to higher power. Furthermore, the increased conductivity of the anolyte will have reduced ohmic losses, thus lowering the internal resistance, another factor assisting performance across the concentrations of 0.4 to $1.6 \mathrm{mmol} \mathrm{L}^{-1}$. The increase in $\mathrm{pH}$ during MFC operation in acidic wastewaters would provide a valuable service for wastewater treatment companies that could negate the need for additional chemicals such as lime.

\subsection{Metal analysis}

Following treatment of $\mathrm{FeCl}_{3}$ concentrations $0.4-1.6 \mathrm{mmol} \mathrm{L}^{-1}$, black particulate matter was accumulating and so it was filtered from the effluent and analysed using EDX which showed it consisted of iron, sulphur and phosphorus (data not shown). Influent prior to treatment and effluent following treatment were filter sterilised and the liquid analysed using ICP-OES. Following treatment, the feedstock with $0.4-1.6 \mathrm{mmol} \mathrm{L}^{-1} \mathrm{FeCl}_{3}$ concentration showed a $17.38 \%$ (SD: 2.07) reduction in soluble iron, 38.47\% (SD: 8.35) reduction in soluble phosphorus and $4.87 \%$ (SD: 0.38 ) reduction in soluble sulphur as illustrated by the black bars in Fig. 4. At the higher $\mathrm{FeCl}_{3}$ concentrations, where there was no precipitation, analysis showed that while there was some reduction, the change was less marked and iron was reduced by $4.14 \%$ (SD: 1.29 ), phosphorus by $8.39 \%$ (SD: 3.06 ) and sulphur by $2.22 \%$ (SD: 2.14) following MFC treatment (Fig. 4, light-coloured bars). In order to examine whether a natural chemical precipitation might occur without passing through the MFCs, all 
concentrations of $\mathrm{FeCl}_{3}$ in feedstock were left to stand for a week, following which no precipitation was observed and no change in $\mathrm{pH}$ or conductivity was recorded. Thus, it is suggested that the changes were catalysed as a result of the anodic reactions. Chemical phosphorus removal and the precipitation of phosphate salts is dependent on both $\mathrm{pH}$ and phosphate concentration. ${ }^{22}$ Furthermore, phosphate removal from MFCs has been demonstrated to be reliant on the solubility of phosphate, which is strongly influenced by

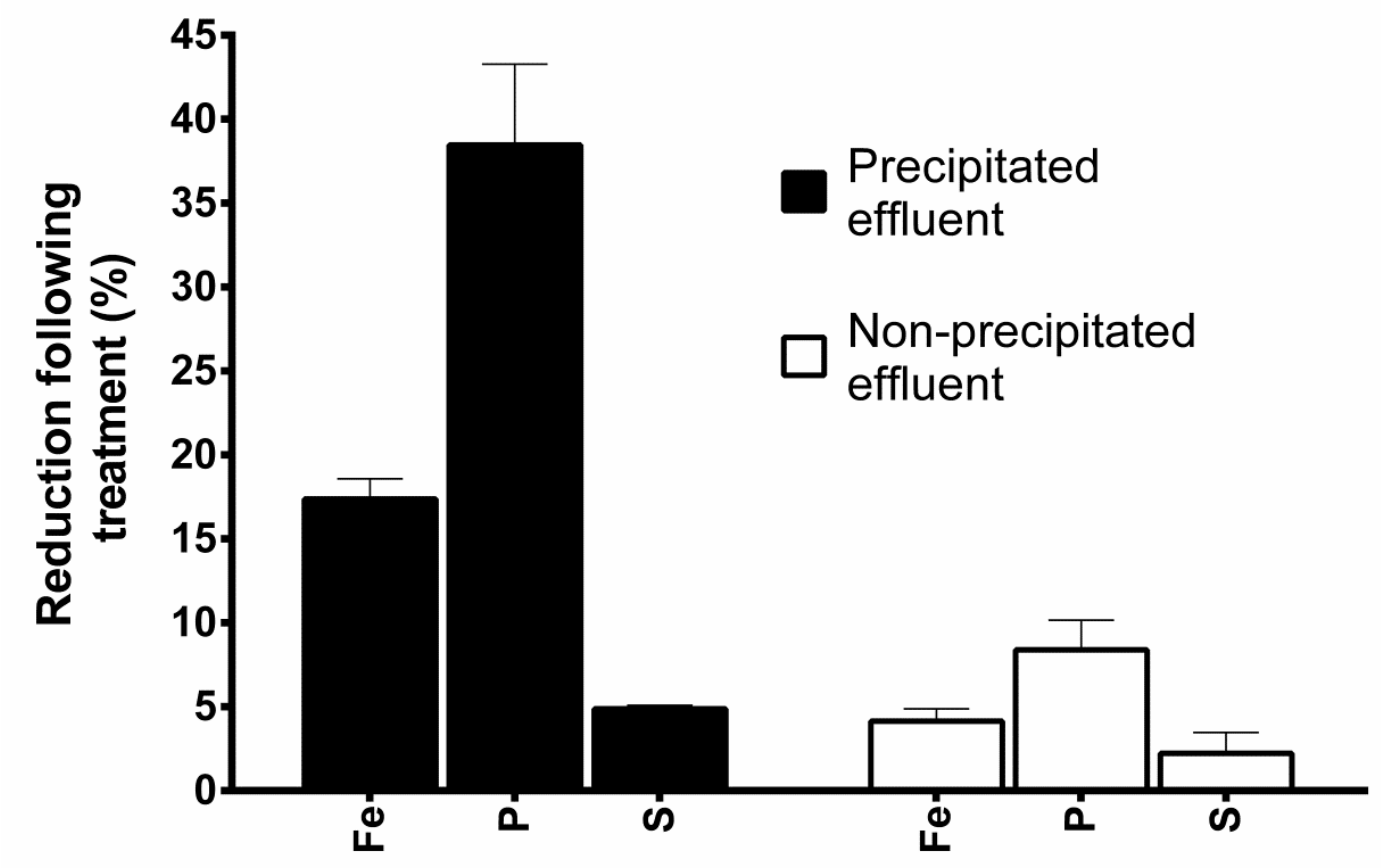

Figure 4. Comparison of the magnitude of soluble Fe, $P$ and $S$ reduction following MFC treatment. Black bars represent feedstock that precipitated $\left(0.4-1.6 \mathrm{mmol} \mathrm{L}^{-1} \mathrm{FeCl}_{3}\right)$ and light bars represent feedstock that did not precipitate $\left(2-2.8 \mathrm{mmol} \mathrm{L}^{-1} \mathrm{FeCl}_{3}\right)$. Data presented as the mean and range $(n=3)$.

$\mathrm{pH}^{23}$ Therefore in the current study it is possible that the significant changes to the phosphate levels were a direct and indirect consequence of the microbial contingent. Direct mechanisms could include bacterial cellular phosphate uptake ${ }^{24}$ or via other mechanisms such as the bioreductive generation of phosphine. ${ }^{25}$ An indirect consequence of biofilm activity was the increase in anolyte $\mathrm{pH}$, which will have made the solution more conducive to chemical precipitation. The effluent following MFC treatment exhibited sewage-like qualities, demonstrated by the black colour and pungent odour, features that indicate the presence of hydrogen sulphide $\left(\mathrm{H}_{2} \mathrm{~S}\right)$. When $\mathrm{H}_{2} \mathrm{~S}$ reacts with metal ions such as iron, metal sulphides are produced (as highlighted by the presence of iron and sulphur in the precipitated particulate matter). $\mathrm{H}_{2} \mathrm{~S}$ is produced in MFCs when sulphate-reducing organisms oxidise the carbon energy source, and subsequently reduce any sulphate present. ${ }^{1,26}$ In addition, other biological 
mechanisms could be playing a role, e.g. via the microbial transformation of amino acids such as cysteine into $\mathrm{H}_{2} \mathrm{~S} .{ }^{27}$ The resulting $\mathrm{H}_{2} \mathrm{~S}$ can act as a shuttle transferring electrons from bacterial cells to the anode surface before oxidising back to sulphate. ${ }^{1,26}$ The recycling of $\mathrm{H}_{2} \mathrm{~S}$ and sulphate could explain why the removal efficiency of sulphur was lower than either iron or phosphorus (Fig. 4). The production of $\mathrm{H}_{2} \mathrm{~S}$ could benefit power production on two fronts: (i) through electron shuttling; and (ii) by increasing the solution conductivity via the production of iron sulphides. The lack of colour or smell at concentrations of $2 \mathrm{mmol} \mathrm{L}^{-1}$ and higher suggests that $\mathrm{H}_{2} \mathrm{~S}$ was not being produced to the same extent, resulting in lower power outputs.

\subsection{COD reduction}

COD reduction was analysed during the second run of experiments at different $\mathrm{FeCl}_{3}$ concentrations. As shown in Fig. 5, influent without the addition of $\mathrm{FeCl}_{3}$ resulted in the highest reduction of COD. The relatively low treatment efficiency of $26 \%$ for the TYE with no added $\mathrm{FeCl}_{3}$ suggests that the flow rate was excessive and the reactor volume insufficiently small $(1 \mathrm{~mL})$ to reduce COD further. For future work this is something that could easily be rectified by operating multiple MFCs in cascade. ${ }^{28-30}$

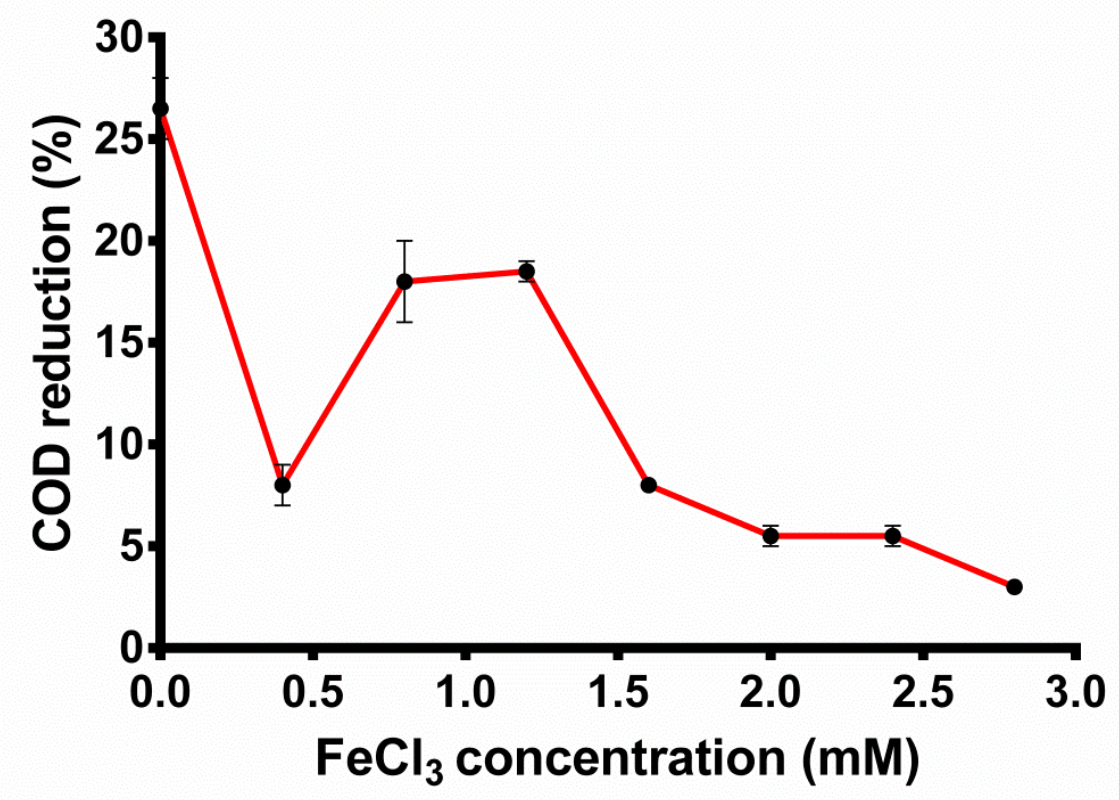

Figure 5. COD reduction following treatment by MFCs at various concentrations of $\mathrm{FeCl}_{3}$. Data presented as the mean and range $(\mathrm{n}=2)$. 
The COD treatment efficiency dropped when the first $\mathrm{FeCl}_{3}$ concentration $\left(0.4 \mathrm{mmol} \mathrm{L}^{-1}\right)$ was introduced (Fig. 5). Treatment efficiency then increased, before stabilising at $1.2 \mathrm{mmol}$ $\mathrm{L}^{-1}$ and then declining all the way to $2.8 \mathrm{mmol} \mathrm{L}^{-1}$. Even though the pattern is similar to the power saturation curves (Fig. 1), it is interesting to observe that at $1.6 \mathrm{mmol} \mathrm{L}^{-1}$, where MFC power output was at its highest, there was still a drop in COD reduction efficiency.

Furthermore, at the highest concentration of $\mathrm{FeCl}_{3}$, where eventually system failure occurred, there was still a reduction in COD albeit a small one (3\%). As discussed earlier, there was no chemical contribution to power and so this cannot explain the unexpected decline in COD efficiency at $1.6 \mathrm{mmol} \mathrm{L}^{-1}$. The low COD removal could be linked to the production of alternative electron donors (i.e. $\mathrm{H}_{2} \mathrm{~S}$ ) that were ultimately utilised as an alternative to carbon as the source of electrons. Other research has demonstrated that the introduction of sulphide can improve the production of electricity in biological fuel cells ${ }^{31}$ but can also generate electricity as a result of chemical reactions in abiotic cells. ${ }^{32}$ Therefore, whilst $\mathrm{H}_{2} \mathrm{~S}$ can improve power output, its presence may have also limited COD reduction. During the first run of experiments the MFCs were intolerant to $2 \mathrm{mmol} \mathrm{L}^{-1} \mathrm{FeCl}_{3}$. Following a further month's adaptation to iron-rich conditions, the MFCs were able to operate at higher concentrations. However, $2.8 \mathrm{mmol} \mathrm{L}^{-1}$ proved to be too adverse an environment for the electro-active members of the anodic community to survive in. Therefore, as well as the obvious decline in power, the redox balance of the MFC on a global level was affected. As previously discussed, the natural chemical redox behaviour of the $\mathrm{MFC}$ when fed $\mathrm{FeCl}_{3}$-rich influent, was to reverse the polarity. The presence of the anodic biofilm was therefore adjusting the redox conditions enabling the reactor to function. The highest concentration inhibited the electro-active microbial contingent, and with the microbes effectively 'silenced' the MFC reverted back to the chemical redox conditions resulting in a negative voltage. Despite this, the conditions will not have inhibited the entire microbial community. There may have been a small proportion of surviving extremophiles that although metabolically active were not able to employ the anode as the final step in their anaerobic respiration. This could explain the continued reduction in $\mathrm{COD}$ at the highest $\mathrm{FeCl}_{3}$ concentrations.

\subsection{MFCs and wastewater treatment}

MFCs could play an important role in wastewater treatment perhaps through integration alongside other treatment technologies. ${ }^{29,33}$ The current study strengthens the case by demonstrating that MFCs can operate in the type of hostile conditions imposed by existing treatment practices. The MFCs' role would need to be customised depending on the specifics 
of the wastewater treatment plant. The results presented herewith indicate that MFCs could operate alongside a separation/filtration process where flocculant-dosing is carried out. While the ultimate goal is the removal of chemical additives from existing practices, it is unlikely that any withdrawal would be immediate. The current research has demonstrated that MFCs could not only fit in alongside flocculant-dosing, but should the use of chemicals be withdrawn the MFCs have displayed the robustness required to adjust to environmental change. Finally, the current study utilised small-scale MFCs over a relatively short experimental period (25 weeks). Further work is ongoing to explore the effect of long-term operation on factors such as biofouling, blockages caused by the build-up of precipitates and responses to changes in other environmental parameters (wastewater composition, temperature, conductivity). It is envisaged that conventional proton exchange membranes will be replaced by larger scale, ceramic reactors that will not only reduce cost but enable operational longevity.

\section{CONCLUSIONS}

The results presented suggest that MFCs could be employed to help improve existing flocculation and/or phosphorus-removal systems, in combination with a separation/filtration process. Fundamentally a MFC's performance is judged on its power-producing and CODreducing capabilities. In this study, the MFCs were able to produce stable power at $\mathrm{FeCl}_{3}$ concentrations likely to be found where the technique of dosing is practised. COD reduction was achieved across all concentrations, and although efficiency was relatively low, it could be quickly improved by running the effluent through a second time or by operating multiple MFCs in a cascade manner (part of a future study). Furthermore, up to a $\mathrm{FeCl}_{3}$ concentration of $2 \mathrm{mmol} \mathrm{L}^{-1}$, the MFCs could not only generate power at $\mathrm{pH}$ starting levels lower than 3.5, but they were also able to neutralise the acidity following treatment. This feature would negate the need to administer additional chemicals such as lime in order to increase $\mathrm{pH}$ following the addition of ferric salts. On top of this, phosphorus, iron and to a lesser extent sulphur concentrations were reduced after passing through the MFCs. These findings demonstrate the versatility of MFCs both in terms of adapting to a hostile environment, and to the array of tasks they may perform.

\section{REFERENCES}

1 Habermann W and Pommer EH, Biological fuel-cells with sulfide storage capacity. Appl Microbiol Biotechnol 35:128-133 (1991). 
2 Royall CP, Aarts DGAL and Tanaka H, Fluid structure in colloid-polymer mixtures: the competition between electrostatics and depletion. J Phys Condens Matter 17:S3401-S3408 (2005).

3 Nielsen AH, Lens P, Vollertsen J and Hvitved-Jacobsen T, Sulfide-iron interactions in domestic wastewater from a gravity sewer. Water Res 39:2747-2755 (2005).

$4 \quad$ Johnson DB and Hallberg KB, Biogeochemistry of the compost bioreactor components of a composite acid mine drainage passive remediation system. Sci Total Environ 338:81-93 (2005).

5 Yuan Y, Chen Q, Zhou SG, Zhuang L and Hu P, Improved electricity production from sewage sludge under alkaline conditions in an insert-type air-cathode microbial fuel cell. JChemTechnol Biotechnol 87:80-86 (2012).

6 Yong Y, Cai Z, Yu Y, Chen P, Jiang R, Cao B, Sun J, Wang J and Song H, Increase of riboflavin biosynthesis underlies enhancement of extracellular electron transfer of Shewanella in alkaline microbial fuel cells. Bioresource Technol 130:763-768 (2013).

7 Jong BC, Kim BH, Chang IS, Liew PWY, Choo YF and Kang GS, Enrichment, performance, and microbial diversity of a thermophilic mediatorless microbial fuel cell. Environ Sci Technol 40:6449-6454 (2006).

8 Miller LG and Oremland RS, Electricity generation by anaerobic bacteria and anoxic sediments from hypersaline soda lakes. Extremophiles 12:837-848 (2008).

9 Michie IS, KimJR, Dinsdale RM, Guwy AJ and Premier GC, The influence of psychrophilic and mesophilic start-up temperature on microbial fuel cell system performance. Energy Environ Sci 4:1011-1019 (2011).

10 Greenman J, Gálvez A, Giusti L and Ieropoulos I, Electricity from landfill leachate using microbial fuel cells: comparison with a biological aerated filter. Enzyme Microbiol Technol 44:112-119 (2009).

11 Ter Heijne A, Hamelers HVM, De Wilde V, Rozendal RA and Buisman CJN, A bipolar membrane combined with ferric iron reduction as an efficient cathode system in microbial fuel cells. Environ Sci Technol 40:5200-5205 (2006).

12 Lefebvre O, Neculita CM, Yue X and Ng HY, Bioelectrochemical treatment of acid mine drainage dominated with iron. J Hazard Mater 241-242:411-417 (2012).

13 Wu D, Xing D, Lu L, Wei M, Liu B and Ren N, Ferric iron enhances electricity generation by Shewanella oneidensis MR-1 in MFCs. Bioresource Technol 135:630634 (2013). 
14 Borole AP, O’Neill H, Tsouris C and Cesar S, A microbial fuel cell operating at low pH using the acidophile Acidiphilium cryptum. Biotechnol Lett 30:1367-1372 (2008).

15 Malki M, De Lacey AL, Rodriguez N, Amils R and Fernandez VM, Preferential use of an anode as an electron acceptor by an acidophilic bacterium in the presence of oxygen. Appl Environ Microbiol 74:4472-4476 (2008).

16 Winfield J, Ieropoulos I, Greenman J and Dennis J, Investigating the effects of fluidic connection between microbial fuel cells. Bioprocess Biosyst Eng 34:477-484 (2011).

17 Zhang H, Sun B, Zhao X and Gao Z, Effect of ferric chloride on fouling in membrane bioreactor. Sep Purif Technol 63:341-347 (2008).

18 Winfield J, Ieropoulos I, Greenman J and Dennis J, The overshoot phenomenon as a function of internal resistance in microbial fuel cells. Bioelectrochemistry 81:22-27 (2011).

19 Cheng S, Dempsey BA and Logan BE, Electricity generation from synthetic acid-mine drainage (AMD) water using fuel cell technologies. Environ Sci Technol 41:8149-8153 (2007).

20 Johnson DB and Hallberg KB, Acid mine drainage remediation options: a review. Sci Total Environ 338:3-14 (2005).

21 Garcia C, Moreno DA, Ballester A, Blazquez ML and Gonzalez F, Bioremediation of an industrial acid mine water by metal-tolerant sulphate-reducing bacteria. Minerals Engineering.14:997-1008 (2001).

22 Carlsson $\mathrm{H}$, Aspegren $\mathrm{H}$, Lee $\mathrm{N}$ and Hilmer A, Calcium phosphate precipitation in biological phosphorus removal systems. Water Res 31:1047-1055 (1997).

23 Puig S, Serra M, Coma M, Cabre M, Balaguer MD and Colprim J, Effect of pH on nutrient dynamics and electricity production using microbial fuel cells. Bioresource Technol 101:9594-9599 (2010).

24 Korstee G, Appeldoorn K, Bonting C, Vanniel E and Vanveen H, Biology of polyphosphate-accumulating bacteria involved in enhanced biological phosphorus removal. FEMS Microbiol Rev 15:137-153 (1994).

25 Jenkins RO, Morris TA, Craig PJ, Ritchie AW and Ostah N, Phosphine generation by mixed- and mono septic-cultures of anaerobic bacteria. Sci Total Environ 250:73-81 (2000).

26 Cooney MJ, Roschi E, Marison IW, Comminellis C and von Stockar U, Physiologic studies with the sulfate-reducing bacterium Desulfovibrio desulfuricans: evaluation for use in a biofuel cell. Enzyme Microbiol Technol 18:358-365 (1996). 
27 Morra MJ and Dick WA, Mechanisms of $\mathrm{H}_{2} \mathrm{~S}$ production from cysteine and cystine by microorganisms isolated from soil by selective enrichment. Appl EnvironMicrobiol 57:1413-1417 (1991).

28 Ieropoulos I, Greenman J, Melhuish C and Horsfield I, EcoBot-III: a robot with guts, in Artificial life XII, Odense, Denmark, ed by Fellermann H, Dorr M, Hanczyc MM, Ladegaard L, Maurer S and Merkle D. MIT Press, Cambridge, MA, 733-740 (2010).

29 Winfield J, Ieropoulos I and Greenman J, Investigating a cascade of seven hydraulically connected microbial fuel cells. Bioresource Technol 110:245-250 (2012).

30 Ledezma P, Stinchcombe A, Greenman J and Ieropoulos I, The first self-sustainable microbial fuel cell stack. Phys Chem Chem Phys 15:2278-2281 (2013).

31 Ieropoulos I, Galvez A and Greenman J, Effects of sulphate addition and sulphide inhibition on microbial fuel cells. EnzymeMicrobiol Technol 52:32-37 (2013).

32 Eaktasang N, Min H, Kang C and Kim HS, Control of malodorous hydrogen sulfide compounds using microbial fuel cell. Bioprocess Biosyst Eng 36:1417-1425 (2013).

$33 \mathrm{Li} \mathrm{W}, \mathrm{Yu} \mathrm{H}$ and He Z, Towards sustainable wastewater treatment by using microbial fuel cells-centered technologies. Energy Environ Sci 7:911-924 (2014). 